\title{
THE USE OF FAIR VALUE ACCOUNTING, BUSINESS OUTCOMES, AND INVESTOR CONFIDENCE FOR SELECTED ROMANIAN AND TURKISH FIRMS
}

\author{
Ibrahim Mert ${ }^{1}$
}

\begin{abstract}
The purpose of this quantitative, correlative, and survey-based study was to determine whether the use of fair value accounting by publicly-listed companies in Turkey and Romania was associated with significant variation in investors' (1) optimism about increases in the company's stock price, (2) likelihood of buying more stock, and (3) evaluation of the company's transparency. After controlling for company size, industry, and geographic location, it was found that the use of fair value accounting is associated with higher investor optimism about stock prices and increased likelihood of investors buying more stock. Investors' evaluations of company transparency did not vary according to whether the company used fair value accounting. Furthermore, based on country-specific analysis, it was concluded that Turkey is justified in its more aggressive adoption of fair value accounting whereas Romania ought to move towards both IFRS in general and fair value accounting in particular. This conclusion was justified by data analysis revealing that Turkish companies are larger are more profitable than Romanian companies in the same industries.
\end{abstract}

Keywords: Fair value accounting, Turkish accounting, Romanian accounting

JEL codes: $M 41$

\section{Introduction}

The purpose of this empirical study was to determine whether the use of fair value accounting among public companies in Turkey and Romania was associated with (a) investor optimism, (b) investor likelihood of purchasing more stock, and (c) investor evaluations of company transparency. While there is extensive literature on fair value accounting, there is an absence of empirical work on investor response to fair value companies. Accordingly, it is unknown whether the use of fair value accounting constitutes a form of competitive advantage or whether investors do not take the use of fair value accounting into consideration when making investment decisions and evaluations. By studying investor response to a stratified and carefully-matched sample of fair value users and non-users, it is possible to determine what effect the use of fair value accounting has on investor response, thus helping to close a gap in the literature.

\section{Literature Review}

In accounting theory, fair value is the price of an asset, good, or service that most accurately reflects current and realistic conditions (Previts, Walton, \& Wolnizer, 2011). Fair value can be distinct from other kinds of value, such as market value and historical value. The market value of a manufacturing plant might be $\$ 1$ billion, but fair value might be considerably lower-perhaps because of the small number of potential number of buyers of such a plant, combined with the fact that potential buyers might already have plants of their own. Thus, the fair value of the manufacturing plant would be lower than its market price. The same kind of reasoning applies to

\footnotetext{
1 “Alexandru Ioan Cuza” University, Iasi, Romania,e-mail: ibrahimm1508@yahoo.com
} 
historic price. For example, the historic price of a parcel of land might be $\$ 10$ million, but appreciation in real estate might mean that the land can easily be sold at $\$ 50$ million. The fair value principle would, in such a scenario, require the value of the land to be recorded at $\$ 50$ million rather than at $\$ 10$ million.

These examples demonstrate that value is a floating concept rather than a fixed one. Accounting is the framework through which value is expressed and assigned (Saudagaran, 2009).

Accounting is a framework that, despite its high level of standardization, can be used and defined in flexible ways by different stakeholders (Dick \& Missionier-Piera, 2010). Accounting is not immune from clashes of interest. In contemporary times one of the big questions pertaining to the measurement and evaluation of accounting systems is how to weight and recognize the interests of different stakeholders within the tripartite discretionary, national, and international practice of accounting (Cline, 2010). Fair value has been suggested as a means of weighting and recognizing interests in the most appropriate fashion (Palepu, Healy, Peek, \& Bernard, 2007; Zack, 2009).

While there is extensive theoretical work on how fair value accounting improves the quality of the market mechanism (Palepu et al., 2007), there is a paucity of empirical work addressing the questions of (1) whether the use of fair value accounting is associated with major variations in key financial metrics such as revenue, profit margin, and stock price growth and (2) whether the use of fair value accounting raises investor optimism. The purpose of this empirical study was to answer these two questions through a statistical analysis conducted on selected Turkish and Romanian companies.

Romania and Turkey are particularly fascinating countries to study in this regard. Both Romania and Turkey are expanding rapidly; for some years past, the Romanian economy has grown faster than that of any other country within the EU, while in recent years Turkey's economic growth rates have only been exceeded by those of China (Pricewaterhouse Coopers, 2012; World Bank, 2012). Turkey and Romania thus face significant incentives to measure and evaluate accounting practices in line with the potential of such practices to keep facilitating economic growth (Vinals, 2010). At the same time, if these countries adopt principles of measurement and evaluation that reward overly aggressive accounting practices, then there is the risk of market backlash (and, in Romania's case, various other EU-mandated penalties that would come from undermining IFRS).

The analysis of Turkish and Romanian companies and investors carried out in this study revealed that the use of fair value accounting was not significantly correlated with variations in revenue, profit, and stock price growth, but was nonetheless encouraging to investors. The details and implications of these findings will be examined in detail.

\section{Methodology}

The study was conducted on 56 publicly-listed companies in Turkey and Romania. The following data were gathered:

- Company: There were 56 companies in the study; each was assigned a number from 1 to 56

- Country: 1 = Turkey; 2 = Romania

- Fair Value: 0 = Does Not Use Fair Value; 1 = Uses Fair Value

- Revenue: Annual revenue in millions of USD

- Profit Margin: Profit margin over most recent fiscal year

- MOM Share Growth: Month-over-month increase in stock price

- YOY Share Growth: Year-over-year increase in stock price

- Industry: 1 = Manufacturing, 2 = Holding Company, 3 = Telecommunications, 4 = Agriculture, $5=$ Technology, $6=$ Financial Services, $7=$ Logistics, $8=$ Construction

- Optimism: A measure of investors' optimism about the company, with $1=$ not at all, $2=$ no, $3=$ not really, $4=$ neutral, $5=$ a little bit, $6=$ yes, $7=$ absolutely 
- Likely to Buy: A measure of investors' likelihood of buying further stock in the company, with $1=$ not at all, $2=$ no, $3=$ not really, $4=$ neutral, $5=$ a little bit, $6=$ yes, $7=$ absolutely

- Company Transparency: A measure of how transparent investors find the company to be, with $1=$ not at all, $2=$ no, $3=$ not really, $4=$ neutral, $5=$ a little bit, $6=$ yes, $7=$ absolutely

Data on country, fair value use, revenue, profit margin, share growth, and industry were drawn from publicly-available databases of listed companies in Turkey and Romania. Data on optimism, likeliness to buy, and company transparency were gathered from a survey of 56 investors, 28 from Turkish markets and 28 from Romanian markets, who were recruited via Facebook. Each investor held stock in exactly one of the companies evaluated in the study. These investors were asked about their optimism, likelihood to buy further stock, and estimation of company transparency.

Of the companies in the sample, 28 used fair value and 28 did not use fair value. Choosing an equal number of companies from each value facilitated the statistical analysis. Moreover, each country had an equal number of fair value-using and non-fair value-using companies. Stratification ensured that 14 each of the Turkish and Romanian companies used fair value accounting, and 14 each did not. Between them, the 56 companies represented manufacturing $(\mathrm{N}=10)$, telecommunications $(\mathrm{N}=3)$, agriculture $(\mathrm{N}=3)$, technology $(\mathrm{N}=10)$, financial services $(\mathrm{N}=7)$, logistics $(\mathrm{N}=8)$, construction $(\mathrm{N}=11)$, and holding companies $(\mathrm{N}=4)$.

\section{Analysis of Company Data}

The first set of inferential tests conducted in the study involved determining whether the use of fair value accounting was associated with more or less (1) revenue, (2) profit margin, (3) monthover-month stock price growth, and (4) year-over-year stock price growth. These tests were conducted using the independent samples $t$-test methodology. If the $p$ value of measured differences between fair value users and fair value non-users was below .05, the difference was isolated further through the use of cross-tabulations and Chi-square analysis. The research hypothesis was that using fair value was associated with higher revenue, profit, month-over-month stock price changes, and year-over-year stock price changes.

The findings were as follows. There was no statistically significant difference between the revenue of fair value users versus non-fair value users $(p=.743)$, the profit margins of fair value users versus non-fair value users $(p=.346)$, the month-over-month stock price growth of fair value users versus non-fair value users $(p=.801)$, or the year-over-year stock price growth of fair value users versus non-fair value users $(p=.505)$. Chi-square analysis also discovered that fair value use was dispersed equally across companies $(p=.312)$, indicating that the findings of non-significance were not skewed by the non-representative distribution of fair value users or non-users in any one industry.

The mean revenue for fair value users $(\mathrm{M}=133.39$ million USD, $s=705.879)$ was not statistically distinguishable $(p=.743)$ from the mean revenue for non-fair value-users $(\mathrm{M}=153.056$ million USD, $s=809.895)$. Similarly, the mean profit margin for fair value users $(\mathrm{M}=4.39 \%, s=$ 4.349) was not statistically distinguishable $(p=.346)$ from the mean profit margin for non-fair value-users $(\mathrm{M}=5.46 \%, s=4.078)$. The mean monthly stock price growth for fair value users (M $=.64 \%, s=2.264)$ was not statistically distinguishable $(p=.801)$ from the mean monthly stock price growth for non-fair value-users $(\mathrm{M}=.5 \%, s=1.953)$. The mean yearly stock growth for fair value users $(\mathrm{M}=6.11 \%, s=5.827)$ was not statistically distinguishable $(p=.505)$ from the mean yearly stock growth for non-fair value-users $(\mathrm{M}=5.11 \%, s=5.315)$. 


\section{Implications of Company Data}

The use of fair value accounting principles was not associated with any statistically significant differences in revenue, profit, or stock growth. While the $t$-tests conducted in this study cannot measure causation, it is still worth noting that the use of fair value accounting was not more prevalent among larger, more profitable, or faster-growing firms. Other variables than these appear to be more significant predictors of fair value use, and fair value use is not itself a predictor of certain kinds of financial excellence.

\section{Analysis of Investor Data}

The second set of inferential tests conducted in the study involved determining whether the use of fair value accounting was associated with more or less (1) investor optimism, (2) investor likelihood to buy more stock in the company, and (3) investor evaluation of company transparency. These tests were conducted using the independent samples $t$-test methodology. The research hypothesis was that using fair value was associated with higher investor optimism, higher investor likelihood to buy more stock, and higher investor evaluation of company transparency. A 7-point Likert scale was used to measure the variables of optimism, likelihood to by more stock, and evaluation of company transparency. The Likert values were $1=$ not at all, $2=$ no, $3=$ not really, 4 $=$ neutral, $5=$ a little bit, $6=$ yes, $7=$ absolutely.

The findings were as follows. (1) Mean investor optimism was much higher for companies that used fair value $(\mathrm{M}=5.04, s=1.503)$ than for companies that did not use fair value $(\mathrm{M}=3.64, s$ $=1.471)$. This difference was statistically significant $(p=.001)$. Chi-square analysis confirmed that investor optimism was unevenly distributed across companies that used fair value versus companies that did not use fair value $(p=.006)$. (2) Mean investor likelihood to buy more stock was higher for companies that used fair value $(\mathrm{M}=5.25, s=1.624)$ than for companies that did not use fair value $(\mathrm{M}=3.75, s=1.555)$. This difference was statistically significant $(p=.001)$. Chi-square analysis confirmed that investor likelihood to buy more stock was unevenly distributed across companies that used fair value versus companies that did not use fair value $(p=.002)$. (3) There was not a statistically difference between evaluations of company transparency for fair value-using companies versus non-fair value-using companies $(p=.189)$.

Mean investor optimism was much higher for companies that used fair value $(\mathrm{M}=5.04, s=$ 1.503) than for companies that did not use fair value $(\mathrm{M}=3.64, s=1.471)$. This difference was statistically significant $(p=.001)$. Chi-square analysis was used to further analyze the difference between investor optimism levels in companies that used fair value versus companies that did not use fair value. Chi-square analysis confirmed that investor optimism was unevenly distributed across companies that used fair value versus companies that did not use fair value $(p=.006)$. The bar chart below (figure 1) clearly depicts the trend observed in the $t$-test, which is that there are higher levels of investor optimism for companies that use fair value versus companies that do not use fair value. 


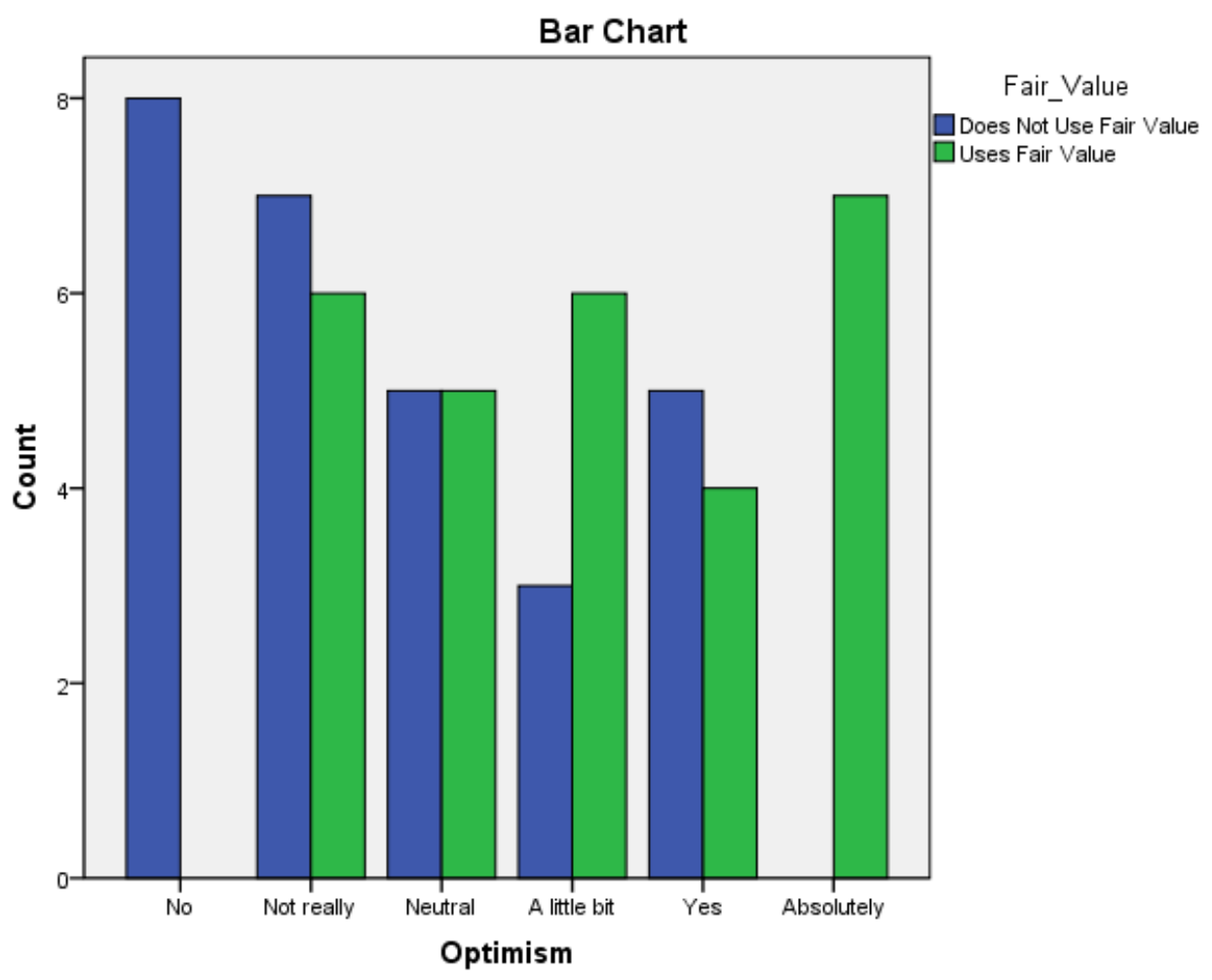

Figure no. 1. - Optimism by Fair Value: Bar Chart

Next, $t$-tests were used to determine whether the use of fair value was also associated with higher investor likelihood of buying more stock, and better investor evaluations of company transparency.

Based on the independent samples $t$-test, mean investor likelihood to buy more stock was higher for companies that used fair value $(\mathrm{M}=5.25, s=1.624)$ than for companies that did not use fair value $(\mathrm{M}=3.75, s=1.555)$. This difference was statistically significant $(p=.001)$. Chi-square analysis was used to further analyze the difference between investor likelihood to buy more stock in companies that used fair value versus companies that did not use fair value. Chi-square analysis confirmed that investor likelihood to buy more stock was unevenly distributed across companies that used fair value versus companies that did not use fair value $(p=.002)$. The bar chart below (figure 2) clearly depicts the trend observed in the $t$-test, which is that there are higher levels of investor likelihood to buy for companies that use fair value versus companies that do not use fair value. 




Figure no. 2 - Likelihood to Buy by Fair Value: Bar Chart

Next, a $t$-test was used to determine whether the use of fair value was also associated with better investor evaluations of company transparency. The difference in investor evaluations of company transparency for fair-value-using and non-fair-value-using companies was not significant $(p=.189)$. However, Chi-square analysis revealed that there were still meaningful differences between the distribution of company transparency evaluations based on fair value usage. The significance of the Chi-square analysis $(p=.005)$ revealed that the distribution of investor evaluations was still not random. It was interesting to note that the only companies to receive 'absolutely' responses to the question of whether they were transparent were also companies that had fair value accounting (see figure 3); similarly, only companies that did not use fair value received the 'no' rating. These differences were too small to register significance in the t-test, but should still be noted. 


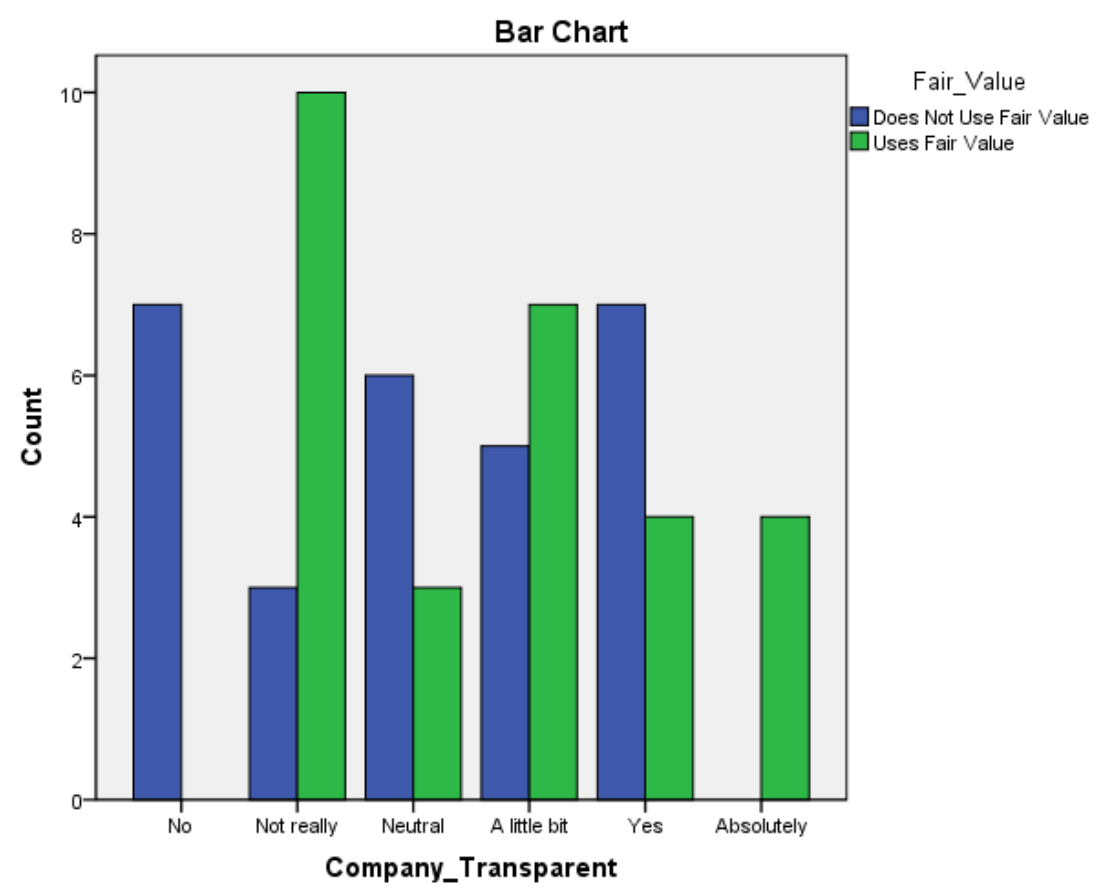

Figure no. 3. - Company Transparency Evaluation by Fair Value: Bar Chart

\section{A Note on Country Differences}

Finally, $t$-tests were conducted on country-level differences in the data. The following results were found. Mean revenue was higher for Turkish companies $(\mathrm{M}=\$ 666.75$ million, $s=$ $1028.153)$ than for Romanian companies $(\mathrm{M}=\$ 262.54$ million, $s=121.191)$. This difference was statistically significant $(p=.048)$. Turkish companies thus appear to generate more revenue than Romanian companies. Mean profit margin was higher for Turkish companies $(\mathrm{M}=6.25, s=3.758)$ than for Romanian companies $(\mathrm{M}=3.61, s=4.289)$. This difference was statistically significant ( $p$ $=.017)$. Turkish companies thus appear to generate more profit margin than Romanian companies. Month-over-month stock price growth was higher for Turkish companies ( $\mathrm{M}=1.29, s=2.070)$ than for Romanian companies $(\mathrm{M}=-.14, s=1.900)$. This difference was statistically significant $(p=$ $.009)$.

\section{Conclusion}

The main finding of the empirical study is that the use of fair value accounting is both recognized and rewarded by investors in the form of higher levels of optimism and higher likelihood of buying more stock but not, at least at an $\alpha$ of .10, with better evaluations of company transparency. It was found that the use of fair value accounting is not associated with significant variations in revenue, profit margin, or stock growth (whether considered on a month-over-month or year-over-year basis). The implications of these findings for Romanian and Turkish accounting and business will now be considered.

For Turkey, the adoption of IFRS, which has driven the interest in fair value accounting in that country (Pricewaterhouse Coopers, 2012) has been driven by a number of interests. Initially, IFRS adoption was seen as a means of signaling that Turkey was ready to the join the European Union (EU), of which it has been a candidate member for several years. Lately, after many Turks began to despair of being admitted into the EU, IFRS adoption began to be seen as a boon to Turkish business interests in an era of globalization and liberalization. In recent years, Turkish economic growth has been extremely rapid, often second only to China (Pope \& Poe, 2011). In this 
environment, Turkish businesses have proven to be increasingly important investment opportunities for individuals and organizations from all over the world. Thus, the adoption of both IFRS and fair value is a means of ensuring Turkish competitiveness in a global investment landscape, given that so many investors are already familiar with IFRS. The results of this study indicate that fair value use does appear to be correlated with measures of investor confidence, so Turkey is justified in its adoption.

Despite the fact that Romania is now a member of the European Union and a functional, vibrant democracy, the accounting system remains weak in many respects (Vinals, 2010). There persists a system of dual accounting in Romania; just as the country has hesitated to accept the Euro, it has also hesitated to make a strong commitment to IFRS or fair value. For Romania, the implication of this study is that fair value adoption is a viable way to drive more investor interest, which will eventually benefit the country and its incorporated companies.

\section{References}

1. Cline W.R., 2010. Financial globalization, economic growth, and the crisis of 2007-09, Washington D.C., Peterson Institute

2. Dick W., Missionier-Piera F., 2010. Financial reporting under IFRS: A topic-based approach, New York, John Wiley \& Sons

3. Palepu K.G., Healy P.M., Peek E., Bernard V.L., 2007. Business analysis and valuation, New York, Cengage

4. Previts G.J., Walton P., Wolnizer P., 2011. A global history of accounting, financial reporting, and republic policy, New York, Emerald Group Publishing

5. Pricewaterhouse Coopers, 2012. New Turkish Commercial Code, available online at http://www.pwc.com/tr/tr/publications/assets/TTK-A_blueprint_for_the_future.pdf

6. Saudagaran S.M., 2009. International accounting: A user perspective, New Delhi, $\mathrm{CCH}$

7. Vinals J., 2010. Romania: Financial sector stability assessment, Washington D.C., International Monetary Fund

8. Zack G.M., 2009. Fair value accounting fraud: New global risks and detection techniques, New York, John Wiley \& Sons

9. ***, World Bank, 2012. Development indicators, available online at http://data.worldbank.org 